\title{
FLAVONOIDS AND PHENYLPROPANOIDS FROM SPATHODEA CAMPANULATA P. BEAUVAIS LEAVES
}

Yaser G. Gouda

Department of Pharmacognosy, Faculty of Pharmacy, Assiut University, Assiut 71526, Egypt.

$$
\begin{aligned}
& \text { أدت تجزئة وتتقية الخلاصة الكحولية لأوراق نبات الاسباثوديا كامبانيو لاتا المنزر ع فى مصر (1) }
\end{aligned}
$$

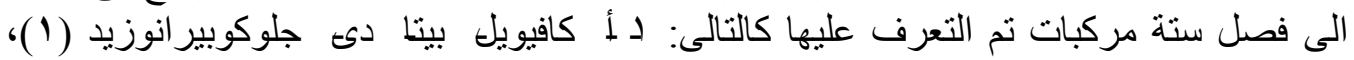

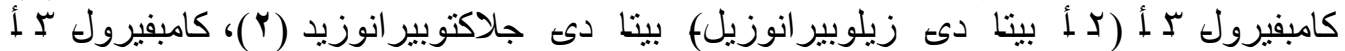

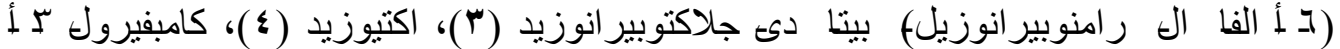

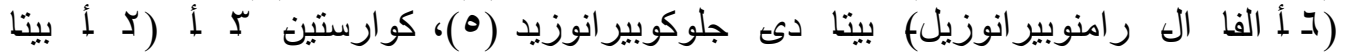

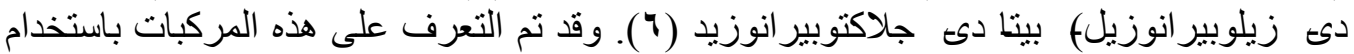

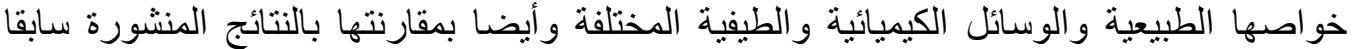

$$
\begin{aligned}
& \text { و هذه المركبات جميعها تفصل لأول مرة من جنس الاسباثوديا. }
\end{aligned}
$$

Fractionation and purification of the methanolic extract of the leaves of Spathodea campanulata $P$. Beauvais cultivated in Egypt afforded six compounds identified as: 1-Ocaffeoyl- $\beta$-D-glucopyranoside (1), kaempferol 3-O-(2-O- $\beta$-D-xylopyranosyl)- $\beta$-D-galactopyranoside (2), kaempferol 3-O-(6-O- $\alpha$-L-rhamnopyranosyl)- $\beta$-D-galactopyranoside (3), acteoside (4), kaempferol 3-O-(6-O- $\alpha$-L-rhamnopyranosyl)- $\beta$-D-glucopyranoside (5) and quercetin 3-O-(2-O- $\beta$-D-xylopyranosyl)- $\beta$-D-galactopyranoside (6). The structures of the isolated compounds were determined by physical, chemical and spectroscopic methods. All these compounds have been isolated for the first time from the genus spathodea.

\section{INTRODUCTION}

Spathodea campanulata P. Beauvais (Bignoniaceae) is widely distributed in Africa $^{1 \& 2}$, known as African tulip tree and cultivated in Egypt as an ornamental plant. It is used in folk medicine as diuretic and antiinflammatory in kidney diseases; for treatment of dysentery, edema, ulcers, filaria, gonorrhoea in addition to healing of wounds and burns ${ }^{1,3-5}$. Reviewing the current literature revealed the presence of anthocyanins in the flowers, sterols, triterpenoides and a cerebroside in the leaves and stem bark $^{6-12}$, phenolic ester (methyl $p$-hydroxy benzoate), phenolic acids ( $p$ hydroxy benzoic, caffeic, ferulic, gallic, protocatechuic, chlorogenic and $p$-coumaric), flavonoids (kaempferol 3-O-glucoside, quercetin 3-methyl ether, 8-methoxy kaempferol 3O-glucoside, apigenin, luteolin, diosmetin, dihydrokaempferol-7-O-(2"-O-formyl)-ß3-D-

glucopyranoside, quercetin, quercetin-3-Oglucoside and quercetin-7-O-glucoside) $)^{3,11-16}$ and iridoids in the roots and leaves ${ }^{3,17-19}$. The insecticidal, hypoglycemic, anticomplement, anti-HIV, antimalarial, antioxidant, antibacterial, antifungal, analgesic, antiinflammatory and molluscicidal activities in addition to wound and burn healing were studied $^{3-5,10-12,20-28}$. The present study includes isolation and structural elucidation of six known compounds (1-6) including four flavonoids and two phenyl propanoids. All compounds which are reported here for the first time in this genus were obtained from the methanolic extract of the air-dried powdered leaves of Spathodea campanulata and characterized by different spectroscopic methods.

\section{EXPERIMENTAL}

\section{General experimental procedure}

Optical rotation was measured on Union PM-101 automatic digital polarimeter. ${ }^{1} \mathrm{H}-$ NMR (400 MHz) and ${ }^{13} \mathrm{C}-\mathrm{NMR}(100 \mathrm{MHz})$ spectra were measured on JEOL JNM A400 spectrometer using TMS as an internal 
standard. UV spectra were determined on Evolution 300 UV-VIS spectrophotometer (England). Column chromatography was performed on Kieselgel 60 (60-230 mesh, Merck), Lichroprep RP-18 (Merck) and Diaion HP-20 (Mitsubishi). Preparative HPLC was carried out on a column of ODS $(150 \times 20 \mathrm{~mm}$ i.d., YMC) with JASCO PU-1580 Pump, JASCO UV-975 UV/visible detector and TOYO SODA RI-8000 refractive index detector. TLC was carried out with silica gel 60 precoated plates F-254 (Merck).

\section{Plant material}

The leaves of Spathodea campanulata P. Beauvais were collected in October 1999 from Aswan Botanical Garden, Aswan, Egypt in the flowering stage. The plant was kindly identified by Prof. Dr. Naeem El-Keltawy, Prof. of Horticulture, Faculty of Agriculture, Assiut University, Assiut, Egypt. A voucher sample (No. 20091) was kept in the Herbarium of Pharmacognosy Department, Faculty of Pharmacy, Assiut University, Assiut, Egypt as reference material.

\section{Extraction and isolation}

The air-dried powdered leaves of Spathodea campanulata P. Beauvais $(4.6 \mathrm{~kg}$ ) was exhaustively extracted with hot methanol by percolation. The methanolic extract was concentrated under reduced pressure till dryness. The residue ( $876 \mathrm{~g}$ ) was suspended in water and extracted with diethyl ether. The aqueous layer after evaporation to a minimum volume, was subjected to a Diaion HP-20 CC and eluted successively with water, $50 \%$ $\mathrm{MeOH}, \mathrm{MeOH}$ and finally with acetone. $40 \mathrm{~g}$ of the residue of $50 \% \mathrm{MeOH}$ eluate $(270 \mathrm{~g})$ was subjected to a silica gel $\mathrm{CC}$ using $\mathrm{CH}_{2} \mathrm{Cl}_{2^{-}}$ $\mathrm{MeOH}-\mathrm{H}_{2} \mathrm{O}$ (90:10:1 to 60:40:10) gradient as eluting systems to give five fractions (Fractions I to Fraction V).

Fraction III (3.5 g) was chromatographed on silica gel $\mathrm{CC}$ using $\mathrm{CH}_{2} \mathrm{Cl}_{2}: \mathrm{MeOH}: \mathrm{H}_{2} \mathrm{O}$ $(80: 20: 2)$ as a solvent system, where three fractions were obtained (Fr-III-1 to Fr-III-3). Fraction Fr-III-1 (1.4 g) was chromatographed on RP-18 CC using 5\% to $20 \% \mathrm{MeCN}$ gradient as eluent, where compounds $1(18 \mathrm{mg})$ and 7 $(20 \mathrm{mg})$ were obtained. Fraction Fr-III-2 (0.8 g) was chromatographed on RP-18 CC using $10 \%$ to $30 \% \mathrm{MeCN}$ gradient as eluent, where three subfractions were obtained (Fr-III-2-1 to Fr-III2-3). Fr-III-2-2 (300 mg) was chromatographed on preparative HPLC using ODS column and $40 \% \mathrm{MeOH}$ as a mobile phase where compounds $2(63 \mathrm{mg})$ and $3(14 \mathrm{mg})$ were obtained. Fr-III-2-3 (166 mg) was chromatographed on preparative HPLC using ODS column and $40 \% \mathrm{MeOH}$ as a mobile phase where compounds 4 (4 mg), 5 (11 mg), 8 $(65 \mathrm{mg})$ and $9(10 \mathrm{mg})$ were obtained. Fraction IV (3.6 g) was chromatographed on silica gel $\mathrm{CC}$ using EtOAc-MeOH- $\mathrm{H}_{2} \mathrm{O}$ (90:10:1 to 80:20:2) gradient as solvent systems to yield two subfractions (Fr-IV-1 and Fr-IV-2). Fr-IV$2(510 \mathrm{mg})$ was purified by preparative ODSHPLC using 35\% $\mathrm{MeOH}$ as eluent where compounds $\mathbf{6}(25 \mathrm{mg}), \mathbf{1 0}(12 \mathrm{mg})$ and 11 (40 $\mathrm{mg}$ ) were obtained. Compounds 7-11 in addition to compounds 12 and 13 which obtained from fraction II and Fr-III-2-1 respectively were identified as iridoids ${ }^{19}$.

\section{Acid hydrolysis}

$10 \mathrm{mg}$ of the compound was hydrolyzed with $0.5 \mathrm{~N} \mathrm{HCl}$ for $1 \mathrm{~h}$. at $95^{\circ} \mathrm{C}$. After neutralization with $\mathrm{BaCO}_{3}$ and extraction with $\mathrm{CHCl}_{3}$, the aqueous layer is dried and the residue is analyzed for the sugar moiety by silica gel TLC using EtOAc (13):MeOH (6): $\mathrm{H}_{2} \mathrm{O}(3): \mathrm{HOAc}$ (3) as solvent system.

Compound (1): Obtained as amorphous powder, $[\alpha]_{\mathrm{D}}^{22}-21.64$ (c $\left.1.71, \mathrm{MeOH}\right) .{ }^{1} \mathrm{H}-$ NMR (400 MHz, $\mathrm{CD}_{3} \mathrm{OD}$ ): aglycone: $\delta 7.64$ $(1 \mathrm{H}, \mathrm{d}, J=15.9 \mathrm{~Hz}, \mathrm{H}-7), 7.05(1 \mathrm{H}, \mathrm{d}, J=1.5$ $\mathrm{Hz}, \mathrm{H}-2), 6.96(1 \mathrm{H}, \mathrm{dd}, J=1.5,8.1 \mathrm{~Hz}, \mathrm{H}-6)$, $6.77(1 \mathrm{H}, \mathrm{d}, J=8.1 \mathrm{~Hz}, \mathrm{H}-5), 6.29(1 \mathrm{H}, \mathrm{d}, J=$ $15.9 \mathrm{~Hz}, \mathrm{H}-8)$, sugar moiety: $\delta 5.56(1 \mathrm{H}, \mathrm{d}, J=$ $\left.7.6 \mathrm{~Hz}, \mathrm{H}-1^{`}\right), 3.83(1 \mathrm{H}$, br d, $J=11.7 \mathrm{~Hz}, \mathrm{H}-$ 6) $3.67\left(1 \mathrm{H}, \mathrm{dd}, J=4.2,11.7 \mathrm{~Hz}, \mathrm{H}-6{ }^{`}\right)$, 3.29 3.45 (4H, m, sugar protons). ${ }^{13} \mathrm{C}-\mathrm{NMR}$ (Table 1).

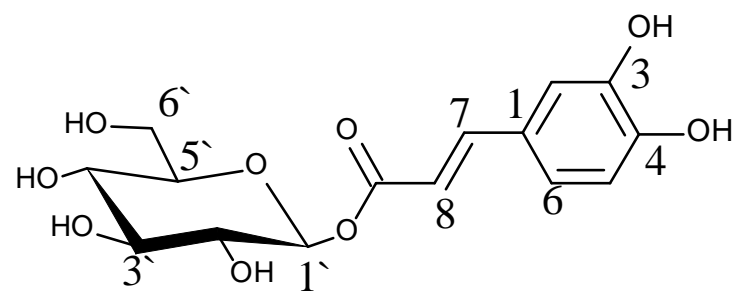


Compound (2): Isolated as amorphous powder, ${ }^{1} \mathrm{H}-\mathrm{NMR}$ (400 MHz, DMSO-d 6 ): aglycone: $\delta 8.11\left(2 \mathrm{H}, \mathrm{d}, J=8.8 \mathrm{~Hz}, \mathrm{H}-2{ }^{\prime}, 6^{\prime}\right)$, $6.86\left(2 \mathrm{H}, \mathrm{d}, J=8.8 \mathrm{~Hz}, \mathrm{H}-3{ }^{`}, 5\right), 6.42(1 \mathrm{H}, \mathrm{br}$ s, H-8), $6.18(1 \mathrm{H}$, br s, H-6), sugar moiety: $\delta$ $5.67\left(1 \mathrm{H}, \mathrm{d}, J=7.6 \mathrm{~Hz}, \mathrm{H}-1^{\prime \prime}\right), 4.54(1 \mathrm{H}, \mathrm{d}, J=$ $\left.7.3 \mathrm{~Hz}, \mathrm{H}-1{ }^{\cdots}\right), 3.04 \sim 3.74(11 \mathrm{H}, \mathrm{m}$, sugar protons). ${ }^{13} \mathrm{C}-\mathrm{NMR}$ (Table 1) and UV/Vis. spectral data (Table 2).<smiles>[R]c1cc(-c2oc3cc(O)cc(O)c3c(=O)c2O)ccc1O</smiles>

2) $\mathrm{R}=\mathrm{H}, \mathrm{R} `=$ xylose $(1 \rightarrow 2)$ galactose

3) $\mathrm{R}=\mathrm{H}, \mathrm{R}^{`}=$ rhamnose $(1 \rightarrow 6)$ galactose

5) $\mathrm{R}=\mathrm{H}, \mathrm{R}^{\prime}=$ rhamnose $(1 \rightarrow 6)$ glucose

6) $\mathrm{R}=\mathrm{OH}, \mathrm{R}^{\prime}=$ xylose $(1 \rightarrow 2)$ galactose

Compound (3): Obtained as amorphous powder, ${ }^{1} \mathrm{H}-\mathrm{NMR} \quad\left(400 \mathrm{MHz}, \quad \mathrm{CD}_{3} \mathrm{OD}\right)$ : aglycone: $\delta 8.08\left(2 \mathrm{H}, \mathrm{d}, J=8.8 \mathrm{~Hz}, \mathrm{H}-2{ }^{\prime}, 6^{\prime}\right)$, $6.87\left(2 \mathrm{H}, \mathrm{d}, J=8.8 \mathrm{~Hz}, \mathrm{H}-3^{`}, 5^{`}\right), 6.39(1 \mathrm{H}, \mathrm{d}$, $J=1.5 \mathrm{~Hz}, \mathrm{H}-8), 6.20(1 \mathrm{H}, \mathrm{d}, J=1.5 \mathrm{~Hz}, \mathrm{H}-6)$, sugar moiety: $\delta 5.03\left(1 \mathrm{H}, \mathrm{d}, J=7.8 \mathrm{~Hz}, \mathrm{H}-1^{`}\right)^{\prime}$, $4.51(1 \mathrm{H}$, br s, H-1 $\cdots), 3.27 \sim 3.80(10 \mathrm{H}, \mathrm{m}$, sugar protons), 1.17 (3H, d, $\left.J=6.3 \mathrm{~Hz}, \mathrm{H}-6^{\cdots}{ }^{\prime}\right)$. ${ }^{13} \mathrm{C}-\mathrm{NMR}$ (Table 1) and UV/Vis. spectral data (Table 2).

Compound (4): Occurs as amorphous powder, ${ }^{1} \mathrm{H}-\mathrm{NMR}$ (400 MHz, $\mathrm{CD}_{3} \mathrm{OD}$ ): aglycone: $\delta 6.59$ $(1 \mathrm{H}, \mathrm{d}, J=2.0 \mathrm{~Hz}, \mathrm{H}-2), 6.57(1 \mathrm{H}, \mathrm{d}, J=8.1$ $\mathrm{Hz}, \mathrm{H}-5), 6.46(1 \mathrm{H}, \mathrm{dd}, J=2.0,8.1 \mathrm{~Hz}, \mathrm{H}-6)$, 3.95 and 3.61 (each 1H, m, H-8), 2.69 (2H, t, $J=7.1$ $\mathrm{Hz}, \mathrm{H}-7)$, sugar moiety: $\delta 4.28(1 \mathrm{H}, \mathrm{d}, J=7.8$ $\left.\mathrm{Hz}, \mathrm{H}-1^{`}\right), 5.08\left(1 \mathrm{H}, \mathrm{d}, J=1.7 \mathrm{~Hz}, \mathrm{H}-1^{\prime \prime}\right)$, 3.20 3.81 (10H, m, sugar protons), $1.00(3 \mathrm{H}, \mathrm{d}$, $\left.J=6.1 \mathrm{~Hz}, 6^{\prime}\right)$, Caffeoyl moiety: $\delta 7.49(1 \mathrm{H}, \mathrm{d}$, $\left.J=15.9 \mathrm{~Hz}, \mathrm{H}-7^{\cdots}\right), 6.95(1 \mathrm{H}, \mathrm{d}, J=2.2 \mathrm{~Hz}, \mathrm{H}-$ $2 “ \cdots), 6.86\left(1 \mathrm{H}, \mathrm{dd}, J=2.2,8.3 \mathrm{~Hz}, \mathrm{H}-6^{\prime \prime}\right)$, $6.68\left(1 \mathrm{H}, \mathrm{d}, J=8.3 \mathrm{~Hz}, \mathrm{H}-5^{\cdots}\right), 6.17(1 \mathrm{H}, \mathrm{d}, J=$ $\left.15.9 \mathrm{~Hz}, \mathrm{H}-8^{\prime \prime}\right) .{ }^{13} \mathrm{C}-\mathrm{NMR}$ (Table 1).

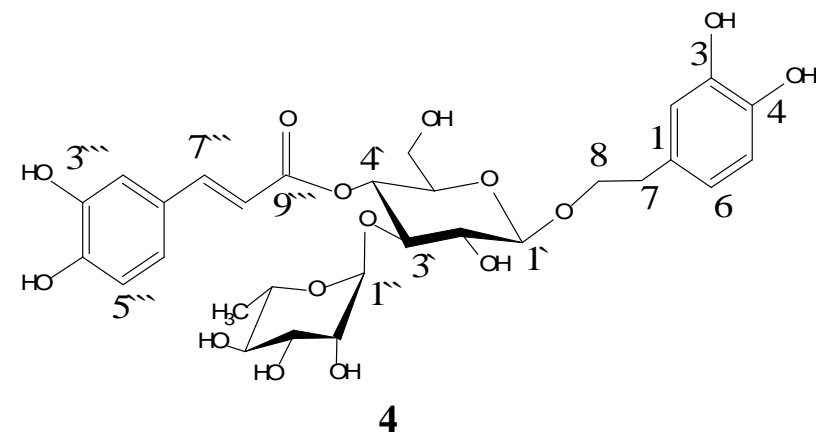

Compound (5): Isolated as amorphous powder, $\quad{ }^{1} \mathrm{H}-\mathrm{NMR} \quad\left(400 \mathrm{MHz}, \quad \mathrm{CD}_{3} \mathrm{OD}\right)$ : aglycone: $\delta 8.05\left(2 \mathrm{H}, \mathrm{d}, J=8.6 \mathrm{~Hz}, \mathrm{H}-2{ }^{`}, 6\right)$, $6.88(2 \mathrm{H}, \mathrm{d}, J=8.6 \mathrm{~Hz}, \mathrm{H}-3 `, 5), 6.40(1 \mathrm{H}, \mathrm{br}$ s, H-8), $6.20(1 \mathrm{H}$, br s, H-6), sugar moiety: $\delta$ $5.11\left(1 \mathrm{H}, \mathrm{d}, J=7.3 \mathrm{~Hz}, \mathrm{H}-1{ }^{\prime}\right), 4.50(1 \mathrm{H}$, br s, H-1 '“), 3.22 3.53 (10H, m, sugar protons), $1.11\left(3 \mathrm{H}, \mathrm{d}, J=6.1 \mathrm{~Hz}, 6{ }^{\prime \prime}\right) .{ }^{13} \mathrm{C}-\mathrm{NMR}$ (Table 1) and UV/Vis. spectral data (Table 2).

Compound (6): Obtained as amorphous powder, ${ }^{1} \mathrm{H}-\mathrm{NMR}$ (400 MHz, DMSO-d $\left.{ }_{6}\right)$ : aglycone: $\left.\delta 7.74(1 \mathrm{H}, \mathrm{dd}, J=2.0,8.5 \mathrm{~Hz}, \mathrm{H}-6)^{\prime}\right)$, $7.51\left(1 \mathrm{H}, \mathrm{d}, J=2.0 \mathrm{~Hz}, \mathrm{H}-2^{\prime}\right), 6.81(1 \mathrm{H}, \mathrm{d}, J=$ $8.5 \mathrm{~Hz}, \mathrm{H}-5$ ) $), 6.38$ (1H, br s, H-8), 6.17 (1H, br s, H-6), sugar moiety: $\delta 5.68(1 \mathrm{H}, \mathrm{d}, J=7.6 \mathrm{~Hz}$, $\left.\mathrm{H}-1{ }^{\prime}\right), 4.54\left(1 \mathrm{H}, \mathrm{d}, J=7.3 \mathrm{~Hz}, \mathrm{H}-1^{\cdots}{ }^{\cdots}\right)$, 3.01 3.77 (11H, m, sugar protons). ${ }^{13} \mathrm{C}-\mathrm{NMR}$ (Table 1) and UV/Vis. spectral data (Table 2). 
Table 1: ${ }^{13} \mathrm{C}-\mathrm{NMR}$ data of compounds 1-6 (100 MHz) in $\mathrm{CD}_{3} \mathrm{OD}$.

\begin{tabular}{|c|c|c|c|c|c|c|}
\hline$C$ & $\begin{array}{c}1 \\
\delta_{\mathrm{C}} \text { (mult.) }\end{array}$ & $\begin{array}{c}\mathbf{2}^{\mathrm{II}} \\
\delta_{\mathrm{C}} \text { (mult.) }\end{array}$ & $\begin{array}{c}\mathbf{3} \\
\delta_{\mathrm{C}} \text { (mult.) } \\
\end{array}$ & $\begin{array}{c}\mathbf{4} \\
\delta_{\mathrm{C}} \text { (mult.) }\end{array}$ & $\begin{array}{c}5 \\
\delta_{C}(\text { mult. }) \\
\end{array}$ & $\begin{array}{c}\boldsymbol{6}^{\mathrm{II}} \\
\delta_{\mathrm{C}} \text { (mult.) } \\
\end{array}$ \\
\hline 1 & $127.6(\mathrm{~s})$ & - & - & $131.5(\mathrm{~s})$ & - & - \\
\hline 2 & $115.2(d)$ & $155.3(156.7)(\mathrm{s})$ & $158.5(156.5)(\mathrm{s})$ & $116.3(\mathrm{~d})$ & $158.5(\mathrm{~s})$ & $155.3(\mathrm{~s})$ \\
\hline 3 & $149.9(\mathrm{~s})$ & $132.9(134.3)(\mathrm{s})$ & $135.7(133.4)(\mathrm{s})$ & $144.7(\mathrm{~s})$ & $135.5(\mathrm{~s})$ & $133.1(\mathrm{~s})$ \\
\hline 4 & $146.9(\mathrm{~s})$ & $177.5(178.6)(\mathrm{s})$ & $179.6(177.4)(\mathrm{s})$ & $146.2(\mathrm{~s})$ & $179.4(\mathrm{~s})$ & $177.4(\mathrm{~s})$ \\
\hline 5 & $116.5(d)$ & $161.3(160.5)(\mathrm{s})$ & $163.0(161.2)(\mathrm{s})$ & $117.1(\mathrm{~d})$ & $163.0(\mathrm{~s})$ & $161.3(\mathrm{~s})$ \\
\hline 6 & $123.2(\mathrm{~d})$ & $98.3(99.3)(\mathrm{d})$ & $100.0(98.9)(\mathrm{d})$ & 121.3(d) & $100.0(\mathrm{~d})$ & $98.4(\mathrm{~d})$ \\
\hline 7 & $148.4(\mathrm{~d})$ & $164.3(163.5)(\mathrm{s})$ & $166.1(164.9)(\mathrm{s})$ & $36.6(t)$ & $166.0(\mathrm{~s})$ & $164.2(\mathrm{~s})$ \\
\hline 8 & $114.4(\mathrm{~d})$ & $93.6(94.8)(\mathrm{d})$ & $94.9(93.9)(\mathrm{d})$ & $72.3(\mathrm{t})$ & $94.9(\mathrm{~d})$ & $93.5(\mathrm{~d})$ \\
\hline 9 & $167.7(\mathrm{~s})$ & $156.3(157.7)(\mathrm{s})$ & $159.4(156.6)(\mathrm{s})$ & - & $159.4(\mathrm{~s})$ & $156.2(\mathrm{~s})$ \\
\hline 10 & - & $103.8(104.2)(\mathrm{s})$ & $105.6(103.8)(\mathrm{s})$ & - & $105.6(\mathrm{~s})$ & $103.8(\mathrm{~s})$ \\
\hline 1 & $95.8(\mathrm{~d})$ & $120.9(121.8)(\mathrm{s})$ & $122.7(120.9)(\mathrm{s})$ & $104.2(\mathrm{~d})$ & $122.7(\mathrm{~s})$ & $121.2(\mathrm{~s})$ \\
\hline 2 & $74.0(\mathrm{~d})$ & $131.0(131.6)(\mathrm{d})$ & $132.5(130.9)(\mathrm{d})$ & $76.2^{\mathrm{a}}(\mathrm{d})$ & $132.3(\mathrm{~d})$ & $115.3(\mathrm{~d})$ \\
\hline 3 & $78.8(\mathrm{~d})$ & $115.2(115.7)(\mathrm{d})$ & $116.1(115.1)(\mathrm{d})$ & $81.7(\mathrm{~d})$ & $116.1(\mathrm{~d})$ & $145.0(\mathrm{~s})$ \\
\hline 4 & $71.1(\mathrm{~d})$ & $160.0(159.2)(\mathrm{s})$ & $161.6(160.0)(\mathrm{s})$ & $70.6^{\mathrm{b}}(\mathrm{d})$ & $161.4(\mathrm{~s})$ & $148.6(\mathrm{~s})$ \\
\hline 5 & $78.0(\mathrm{~d})$ & $115.2(115.7)(\mathrm{d})$ & $116.1(115.3)(\mathrm{d})$ & $76.1^{\mathrm{a}}(\mathrm{d})$ & $116.1(\mathrm{~d})$ & $115.8(\mathrm{~d})$ \\
\hline 6 & $62.3(\mathrm{t})$ & $131.0(131.6)(\mathrm{d})$ & $132.5(130.9)(\mathrm{d})$ & $62.4(\mathrm{t})$ & $132.3(\mathrm{~d})$ & $122.3(\mathrm{~d})$ \\
\hline $1 "$ & & $98.7(100.9)(\mathrm{d})$ & $105.5(102.2)(\mathrm{d})$ & $103.0(\mathrm{~d})$ & $104.6(d)$ & $98.7(\mathrm{~d})$ \\
\hline $2^{\prime \prime}$ & & $79.7(78.8)(\mathrm{d})$ & $73.0(71.2)(\mathrm{d})$ & $72.4(\mathrm{~d})$ & $75.7(d)$ & $79.9(\mathrm{~d})$ \\
\hline 3 & & $73.6(73.9)(d)$ & $75.1(73.0)(\mathrm{d})$ & $72.1(\mathrm{~d})$ & $78.1(\mathrm{~d})$ & $73.7(\mathrm{~d})$ \\
\hline 4 & & $67.8(69.3)(d)$ & $70.2(68.3)(\mathrm{d})$ & $73.8(\mathrm{~d})$ & $71.4(\mathrm{~d})$ & $67.8(d)$ \\
\hline 5 & & $73.9(74.3)(\mathrm{d})$ & $75.4(73.6)(\mathrm{d})$ & $70.4^{b}(d)$ & $77.2(\mathrm{~d})$ & $74.0(\mathrm{~d})$ \\
\hline 6 & & $60.0(61.0)(\mathrm{t})$ & $67.4(65.4)(\mathrm{t})$ & $18.4(q)$ & $68.5(\mathrm{t})$ & $60.0(\mathrm{t})$ \\
\hline 1". & & $104.6(104.9)(\mathrm{d})$ & $101.9(100.1)(\mathrm{d})$ & $127.7(\mathrm{~s})$ & $102.4(\mathrm{~d})$ & $104.7(\mathrm{~d})$ \\
\hline $2 \lll$ & & $75.9(75.5)(\mathrm{d})$ & $72.3(70.7)^{\mathrm{a}}(\mathrm{d})$ & $114.7(\mathrm{~d})$ & $72.3(\mathrm{~d})$ & $75.9(\mathrm{~d})$ \\
\hline 3 & & $76.2(76.3)(\mathrm{d})$ & $72.1(70.5)^{\mathrm{a}}(\mathrm{d})$ & $149.8(\mathrm{~s})$ & $72.1(\mathrm{~d})$ & $76.2(\mathrm{~d})$ \\
\hline 4 & & $69.4(70.1)(\mathrm{d})$ & $73.9(72.0)(\mathrm{d})$ & $146.9(\mathrm{~s})$ & $73.9(\mathrm{~d})$ & $69.5(\mathrm{~d})$ \\
\hline $5 \cdots$ & & $65.8(65.9)(\mathrm{t})$ & $69.7(68.1)(\mathrm{d})$ & $116.5(\mathrm{~d})$ & $69.7(d)$ & $65.7(\mathrm{t})$ \\
\hline 6 & & & $18.0(17.9)(q)$ & $123.2(\mathrm{~d})$ & $17.9(\mathrm{q})$ & \\
\hline $7^{\prime \prime}$ & & & & $148.0(\mathrm{~d})$ & & \\
\hline $8^{\prime \prime \prime}$ & & & & $115.2(\mathrm{~d})$ & & \\
\hline 9 9". & & & & $168.3(\mathrm{~s})$ & & \\
\hline
\end{tabular}

II Measured in DMSO- $d_{6}$

Data between parentheses are in $\mathrm{D}_{2} \mathrm{O}$ for $\mathbf{2}$ and DMSO- $d_{6}$ for $\mathbf{3}$

${ }^{\mathrm{a}, \mathrm{b}}$ chemical shifts in each column maybe interchangeable

Table 2: UV data of compounds $\mathbf{2 , 3 , 5}$ and $\mathbf{6}$ in $\mathrm{MeOH}$ and with different ionizing and complexing reagents.

\begin{tabular}{|c|c|c|c|c|c|c|c|c|c|c|c|c|c|c|}
\hline \multirow[b]{2}{*}{ C. } & \multicolumn{2}{|c|}{$\mathrm{MeOH}$} & \multicolumn{3}{|c|}{ NaOMe } & \multicolumn{3}{|c|}{$\mathrm{NaOAc}$} & \multicolumn{3}{|c|}{$\mathrm{AlCl}_{3}$} & \multicolumn{3}{|c|}{$\mathrm{AlCl}_{3} / \mathrm{HCl}$} \\
\hline & $\begin{array}{c}\text { Band } \\
\text { II }\end{array}$ & $\begin{array}{c}\text { Band } \\
\text { I }\end{array}$ & $\begin{array}{c}\text { Band } \\
\text { II }\end{array}$ & $\begin{array}{c}\text { Band } \\
\text { I }\end{array}$ & $\begin{array}{l}\Delta \lambda_{\max } \\
\text { in } \\
\text { band I }\end{array}$ & $\begin{array}{c}\text { Band } \\
\text { II }\end{array}$ & $\begin{array}{c}\text { Band } \\
\text { I }\end{array}$ & $\begin{array}{c}\Delta \lambda_{\max } \\
\text { in } \\
\text { band II }\end{array}$ & $\begin{array}{c}\text { Band } \\
\text { II }\end{array}$ & $\begin{array}{c}\text { Band } \\
\text { I }\end{array}$ & $\begin{array}{l}\Delta \lambda_{\max } \\
\text { in } \\
\text { band I }\end{array}$ & $\begin{array}{c}\text { Band } \\
\text { II }\end{array}$ & $\begin{array}{c}\text { Band } \\
\text { I }\end{array}$ & $\begin{array}{c}\Delta \lambda_{\max } \\
\text { in } \\
\text { band I }\end{array}$ \\
\hline 2 & 267 & 350 & 275 & 397 & +47 & 274 & 376 & +7 & 275 & 396 & +46 & 276 & 396 & +46 \\
\hline 3 & 267 & 349 & 276 & 399 & +50 & 275 & 382 & +8 & 275 & 397 & +48 & 275 & 396 & +47 \\
\hline 5 & 266 & 349 & 275 & 398 & +49 & 275 & 384 & +9 & 275 & 397 & +48 & 275 & 397 & +48 \\
\hline 6 & 256 & 356 & 272 & 407 & +51 & 274 & 381 & +18 & 275 & 432 & +76 & 269 & 406 & +50 \\
\hline
\end{tabular}




\section{RESULTS AND DISCUSSION}

\section{Compound 1}

Inspection of the ${ }^{13} \mathrm{C}$ and DEPT ${ }^{13} \mathrm{C}-\mathrm{NMR}$ spectral data (Table 1) revealed the presence of fifteen signals equivalent to fifteen carbon atoms. Six signals at $\delta_{\mathrm{C}} 95.8,78.8,78.0,74.0$, 71.1 and 62.3 with their ${ }^{1}$ H-NMR data suggested the presence of glucose moiety ${ }^{29 \& 30}$. The ${ }^{1} \mathrm{H}-\mathrm{NMR}$ spectrum also showed the presence of five peaks in the aromatic region, three of them at $\delta_{\mathrm{H}} 7.05(1 \mathrm{H}, \mathrm{d}, J=1.5 \mathrm{~Hz}), 6.96$ $(1 \mathrm{H}, \mathrm{dd}, J=1.5,8.1 \mathrm{~Hz})$ and $6.77(1 \mathrm{H}, \mathrm{d}, J=$ $8.1 \mathrm{~Hz}$ ) indicated the presence of trisubstituted benzene ring with $\mathrm{ABX}$ system; the other two peaks with their large coupling constant at $\delta_{\mathrm{H}}$ 7.64 and 6.29 (each $1 \mathrm{H}, \mathrm{d}, J=15.9 \mathrm{~Hz}$ ) indicated the presence of trans olefinic protons. These five peaks with the signal at $\delta_{\mathrm{C}} 167.7$ in addition to the remaining 8 signals in the ${ }^{13} \mathrm{C}$ NMR spectrum indicated the presence of trans caffeoyl moiety. The glucose is confirmed to be in $\beta$-configuration from the coupling constant of the anomeric proton at $\delta_{\mathrm{H}} 5.56(1 \mathrm{H}$, $\mathrm{d}, J=7.6 \mathrm{~Hz}$ ) while the attachment between glucose and caffeoyl moiety was confirmed from HMBC experiment where a correlation peak was observed between the anomeric sugar proton at $\delta_{\mathrm{H}} 5.56$ and the carbonyl carbon $\delta_{\mathrm{C}}$ 167.7 and from the reported data of a related compound $^{29}$.

From the above mentioned data compound 1 was identified as 1-O-trans-caffeoyl- $\beta$-Dglucopyranoside ${ }^{31}$ and isolated here for the first time from the genus Spathodea.

\section{Compound 2}

The ${ }^{13} \mathrm{C}$-NMR spectrum of the compound showed the presence of 24 signals equivalent to 26 carbon atoms. The DEPT ${ }^{13} \mathrm{C}-\mathrm{NMR}$ spectrum showed the presence of 9 quaternary, 15 methine and 2 methylene carbon atoms. Thirteen signals equivalent to 15 carbon atoms were identical to a flavonoid skeleton ${ }^{32} \& 33$ and the remaining 11 signals for sugar moiety. The flavonoid skeleton was confirmed from the characteristic two bands (band I and band II) in the UV/Vis. spectrum ${ }^{34}$ and the UV/Vis. spectral data (Table 2) of the compound with different ionizing and complexing reagents which revealed the presence of free hydroxyl group at C-4 position from the bathochromic shift in band I by $47 \mathrm{~nm}$ in presence of sodium methoxide comparing with $\mathrm{MeOH}$, free hydroxyl group at C-7 position from the bathochromic shift in band II by $7 \mathrm{~nm}$ in presence of sodium acetate, presence of free hydroxyl group at position C-5 and absence of ortho-dihydroxy groups from the bathochromic shift in band I by $46 \mathrm{~nm}$ in presence of $\mathrm{AlCl}_{3}$ and the stability of the $\mathrm{AlCl}_{3}$ complex after addition of $\mathrm{HCl}^{34}$. The ${ }^{1} \mathrm{H}-\mathrm{NMR}$ data revealed the presence of two peaks at $\delta_{\mathrm{H}} 8.11$ and 6.86 (each $2 \mathrm{H}, \mathrm{d}, J=8.8 \mathrm{~Hz}$ ) indicating the presence of $p$-disubstituted benzene ring which is confirmed by the signals in the ${ }^{13} \mathrm{C}-\mathrm{NMR}$ spectrum at $\delta_{\mathrm{C}} 160.0$ (1C-s), 120.9 (1C-s), 131.0 and 115.2 (each 2C-d). These signals in addition to peaks at $\delta_{\mathrm{H}} 6.42$ and 6.18 (each $1 \mathrm{H}$, br s) with $\delta_{\mathrm{C}} 93.6$ and 98.3 respectively and 3 signals at $\delta_{\mathrm{C}} 155.54$ (1C-s), 132.9 (1C-s) and 177.5 (1C-s) confirmed also the presence kaempferol moiety ${ }^{32}$.

The ${ }^{1} \mathrm{H}-\mathrm{NMR}$ spectrum suggested the presence of the two sugars in $\beta$ - configuration from the two anomeric protons with their large coupling constants at $\delta_{\mathrm{H}} 5.67(1 \mathrm{H}, \mathrm{d}, J=7.6$ $\mathrm{Hz})$ and $4.54(1 \mathrm{H}, \mathrm{d}, J=7.3 \mathrm{~Hz})$. The ${ }^{13} \mathrm{C}-\mathrm{NMR}$ data showed the anomeric carbons at $\delta_{\mathrm{C}} 98.7$ (d) 104.6 (d) while other atoms were observed at $\delta_{\mathrm{C}} 79.7,76.2,75.9,73.9,73.6,67.8,69.4$ (each 1C-d) for the oxygenated methines and at $\delta_{\mathrm{C}} 60.0,65.8$ (each 1C-t) for the two methylene groups.

From the above chemical shifts and comparing with the literature ${ }^{32 \& 33}$, the sugars were suggested to be galactose and xylose and confirmed by acid hydrolysis ${ }^{34}$ followed by TLC alongside authentic sugars in the previously mentioned solvent system and other solvent systems.

The position of the sugar moiety was deduced to be at C-3 of the kaempferol moiety from the following: the free hydroxyl groups at C-4, C-5 and C-7 deduced from the UV/Vis spectral data (Table 2); the dark purple colour of the compound under UV lamp changed to yellow with $\mathrm{NH}_{3}$; the upfield shift of C-3 (-2.7 ppm), downfield shift of C-4 (+1.5 ppm) and pronounced downfield shift of $\mathrm{C}-2(+8.5 \mathrm{ppm})$ comparing with kaempferol ${ }^{32 \& 33}$. The attachment of xylose to C-2" of galactose was determined from the downfield shift of C-2" of galactose comparing with kaempferol-3-O- $\beta$-Dgalactopyranoside (trifolin) ${ }^{32}$. 
From these data and comparing with the literature ${ }^{32 \& 33}$, compound $\mathbf{2}$ was identified as kaempferol 3-O-(2-O- $\beta$-D-xylopyranosyl)- $\beta$-Dgalactopyranoside and to the best of our knowledge this compound is isolated here for the first time from the genus Spathodea.

\section{Compound 3}

The ${ }^{13} \mathrm{C}$-NMR spectrum of compound $\mathbf{3}$ showed certain similarity to compound $\mathbf{2}$ where 25 signals were observed equivalent to 27 carbon atoms. 19 of them equivalent to 21 carbon atoms are identical with that of $\mathbf{2}$ indicating the presence of kaempferol and galactose sugar moieties and as in compound $\mathbf{2}$ the keampferol moiety was confirmed from the UV/Vis. data in $\mathrm{MeOH}$ and with different ionizing and complexing reagents (Table 2). The remaining signals were observed at $\delta_{\mathrm{H}} 4.51$ $\left(1 \mathrm{H}\right.$, br s) with $\delta_{\mathrm{C}} 101.9$ and at $\delta_{\mathrm{H}} 1.17(3 \mathrm{H}, \mathrm{d}$, $J=6.3 \mathrm{~Hz})$ with $\delta_{\mathrm{C}} 18.0$ in addition to 4 oxygenated methine signals at $\delta_{\mathrm{C}} 72.3,72.1$, 73.9 and 69.7 indicated the presence of $\alpha$ rhamnose sugar moiety ${ }^{35}$. The attachment between the two sugars was confirmed to be between C- 6 of galactose and C- 1 of rhamnose from the downfield shift of C- 6 of galactose $\left(\delta_{C}\right.$ 67.4) comparing with kaempferol-3-O- $\beta$-Dgalactopyranoside (trifolin) ${ }^{32}$. The sugar is attached to C-3 of the kaempferol moiety as in compound 2.

From the abovementioned data, compound 3 was assigned as kaempferol 3-O-(6-O- $\alpha-\mathrm{L}-$ rhamnopyranosyl)- $\beta$-D-galactopyranoside $32 \& 36$ which is isolated here for the first time from the genus Spathodea.

\section{Compound 4}

The ${ }^{1} \mathrm{H}$ and ${ }^{13} \mathrm{C}$-NMR spectra including DEPT mode measurements revealed the presence of two sugar units most probably $\beta$ glucose and $\alpha$-rhamnose from the signals at $\delta_{\mathrm{C}}$ 104.2 with $\delta_{\mathrm{H}} 4.28(1 \mathrm{H}, \mathrm{d}, J=7.8 \mathrm{~Hz})$ for the anomeric carbon and proton of the $\beta$-glucose unit and at $\delta_{\mathrm{C}} 103.0$ with $\delta_{\mathrm{H}} 5.08(1 \mathrm{H}, \mathrm{d}, J=1.7$ $\mathrm{Hz})$ and at $\delta_{\mathrm{C}} 18.4$ with $\delta_{\mathrm{H}} 1.00(3 \mathrm{H}, \mathrm{d}, J=6.1$ $\mathrm{Hz})$ for the anomeric carbon and proton and methyl group of $\alpha$-rhamnose unit respectively ${ }^{37}$.

The ${ }^{1} \mathrm{H}-\mathrm{NMR}$ revealed the presence of eight signals in the aromatic region including two trisubstituted benzene rings with $\mathrm{ABX}$ system and two olefinic protons; these signals were observed at $\delta_{\mathrm{H}} 6.59(1 \mathrm{H}, \mathrm{d}, J=2.0 \mathrm{~Hz}), \delta_{\mathrm{H}}$ $6.57(1 \mathrm{H}, \mathrm{d}, J=8.1 \mathrm{~Hz})$ and $\delta_{\mathrm{H}} 6.46(1 \mathrm{H}, \mathrm{dd}, J=$ $2.0,8.1 \mathrm{~Hz})$ for the first trisubstituted benzene ring and at $\delta_{\mathrm{H}} 6.95(1 \mathrm{H}, \mathrm{d}, J=2.2 \mathrm{~Hz}) \delta_{\mathrm{H}} 6.86$ $(1 \mathrm{H}, \mathrm{dd}, J=2.2,8.3 \mathrm{~Hz})$ and $\delta_{\mathrm{H}} 6.68(1 \mathrm{H}, \mathrm{d}, J=$ $8.3 \mathrm{~Hz}$ ) for the second trisubstituted ring; the olefinic protons were confirmed to be in trans configuration from the large coupling constant that observed at $\delta_{\mathrm{H}} 7.49$ and 6.17 (each $1 \mathrm{H}, \mathrm{d}$, $J=15.9 \mathrm{~Hz}$ ).

The ${ }^{13} \mathrm{C}$, DEPT ${ }^{13} \mathrm{C}-\mathrm{NMR}$ (Table 1) and ${ }^{1} \mathrm{H}$ NMR data revealed the presence of an ethylene group at $\delta_{\mathrm{C}} 36.6$ with $\delta_{\mathrm{H}} 2.69(2 \mathrm{H}, \mathrm{t}, J=7.1 \mathrm{~Hz})$ and $\delta_{\mathrm{C}} 72.3$ with $\delta_{\mathrm{H}} 3.61,3.95$ (each $1 \mathrm{H}, \mathrm{m}$ ) and a carbonyl carbon at $\delta_{\mathrm{C}} 168.3$ which in addition to the signals of the two benzene rings and the trans olefinic protons suggested the presence of 3,4-dihydroxy phenethyl alcohol $^{35,38}$ and caffeoyl moieties ${ }^{39}$

The attachment of 3,4-dihydroxy phenethyl alcohol to C-1 of glucose was confirmed from the chemical shift of the methylene group at $\delta_{\mathrm{C}} 72.3$ and rhamnose to C3 of glucose from the downfield shift of this carbon to $\delta_{\mathrm{C}} 81.7$ and caffeoyl to C-4 from the reported data of acteoside.

From the abovementioned data and the reported data ${ }^{37 \& 39}$, compound 4 was assigned as 3,4-dihydroxyphenethyl alcohol 8-O-[(4-Ocaffeoyl)-3`-O- $\alpha$-L-rhamnopyranosyl-( $(1 \rightarrow 3)]$ $\beta$-D-glucopyranoside (acteoside). This compound is isolated here for the first time from the genus Spathodea.

\section{Compound 5}

The NMR spectral data of 5 including ${ }^{1} \mathrm{H}$, ${ }^{13} \mathrm{C}$ and DEPT ${ }^{13} \mathrm{C}$ mode measurements were also similar to some extent to that of $\mathbf{2}$ and $\mathbf{3}$. Thirteen signals in the ${ }^{13}$ C-NMR spectrum equivalent to 15 carbon atoms having the same chemical shifts with the UV/Vis. spectral data (Table 2) suggested the presence of the kaempferol moiety ${ }^{32 \& 34}$. The remaining 12 signals with their chemical shifts at $\delta_{\mathrm{C}} 104.6$ (1C-d), 102.4 (1C-d), 68.5 (1C-t), 17.9 (1C-q) and oxygenated methines in the region between $\delta_{\mathrm{C}} 69.7$ and 78.1 (each 1C-d) (Table 1) indicated the presence of two sugar units most probably glucose and rhamnose comparing with the reported data ${ }^{32 \& 38}$. The ${ }^{1} \mathrm{H}-\mathrm{NMR}$ data revealed the presence of glucose in $\beta$ - 
configuration from coupling constant of the anomeric proton which appears at $\delta_{\mathrm{H}} 5.11(1 \mathrm{H}$, $\mathrm{d}, J=7.3 \mathrm{~Hz})$ and rhamnose in $\alpha$-configuration at $\delta_{\mathrm{H}} 4.50(1 \mathrm{H}$, br s$)$. The attachment between the two sugar units was confirmed to be between C- 6 of glucose and C-1 of rhamnose from the downfield shift of C- 6 of glucose and comparing with the reported data ${ }^{32,33 \& 38}$. The sugar is attached to C-3 of the kaempferol moiety as in compound $\mathbf{2}$.

From the previous data, compound $\mathbf{5}$ was identified as kaempferol 3-O-(6-O- $\alpha-\mathrm{L}-$ rhamnopyranosyl)- $\beta$-D-glucopyranoside and to the best of our knowledge; this compound is isolated here from the genus Spathodea for the first time.

\section{Compound 6}

The ${ }^{13} \mathrm{C}$-NMR data (Table 1) showed the presence of 26 signals equivalent to 26 carbon atoms. 11 signals with their ${ }^{1} \mathrm{H}-\mathrm{NMR}$ data were identical to that of $\mathbf{2}$ indicating the presence of galactose and xylose sugar moieties, these signals appeared at $\delta_{\mathrm{C}} 104.7,98.7$ with $\delta_{\mathrm{H}} 4.54$ $(1 \mathrm{H}, \mathrm{d}, J=7.3 \mathrm{~Hz})$ and $5.68(1 \mathrm{H}, \mathrm{d}, J=7.6 \mathrm{~Hz})$ for the anomeric carbons and protons of xylose and galactose respectively, the other sugar atoms appeared at $\delta_{\mathrm{C}} 65.7,60.0$ for the two methylene groups and seven oxygenated methines between $\delta_{\mathrm{C}} 67.8$ and 79.2 with $\delta_{\mathrm{H}}$ 3.01-3.77 for the remaining protons. The attachment between the two sugar units were confirmed to be between C-2" of galactose and C-1 ${ }^{\prime \prime}$ of xylose from the resemblance to compound $\mathbf{2}$ and from the reported data ${ }^{32}$.

The remaining 15 signals in the ${ }^{13} \mathrm{C}-\mathrm{NMR}$ spectrum with their ${ }^{1} \mathrm{H}-\mathrm{NMR}$ data were assigned as a flavonoid ${ }^{33}$. The presence of 5 protons in the aromatic region, 3 of them with ABX system at $\delta_{\mathrm{H}} 7.51(1 \mathrm{H}, \mathrm{d}, J=2.0 \mathrm{~Hz})$, $6.81(1 \mathrm{H}, \mathrm{d}, J=8.5 \mathrm{~Hz})$, and $7.74(1 \mathrm{H}, \mathrm{dd}, J=$ $2.0,8.5 \mathrm{~Hz}$ ) and two broad singlets at $\delta_{\mathrm{H}} 6.17$ and 6.38 (each $1 \mathrm{H})$ indicated the presence of quercetin nucleus ${ }^{33}$. The UV/Vis. data in $\mathrm{MeOH}$ and with different ionizing and complexing reagents (Table 2) confirmed the quercetin nucleus from the following: the bathochromic shifts in presence of sodium methoxide and sodium acetate for the free hydroxyl groups at C-4 and C-7 respectively as in compound $\mathbf{2}$; the presence of free hydroxyl group at C-5 and ortho-dihydroxy group at $\mathrm{C}-3$ and 4 from the bathochromic shift in presence of $\mathrm{AlCl}_{3}$ and hypsochromic shift but not to the original value as in $\mathrm{MeOH}$ after addition of $\mathbf{H C l}$. and as in $\mathbf{2}$ the sugar is attached to C-3 of the quercetin moiety.

Comparing with the reported data ${ }^{32 \& 33}$, compound 6 was identified as quercetin 3-O(2-O- $\beta$-D-xylopyranosyl)- $\beta$-D-galactopyranoside and this compound was isolated here for the first time from the genus Spathodea.

\section{Acknowledgments}

The author is grateful to the Research Center of Molecular Medicine of the Hiroshima University School of Medicine, Japan, for NMR measurements.

\section{REFERENCES}

1- F. R. Irvine, "Woody Plants of Ghana", Oxford University Press, London, 1961, pp. 739-740.

2- B. L. Burst and A. H. Gentry, "Flore du Cameroun, Museum Nationale d'Histoire Naturelle", Paris, 27, 44-46, (1984).

3- A. Pianaro, J. P. Pinto, D. T. Ferreira, N. K. Ishikawa and R. Braz-Filho, "Iridoid Glucoside and Antifungal Phenolic Compounds from Spathodea campanulata Roots", Semina, Ciências Agrárias, Londrina, 28, 251-256 (2007).

4- A. Y. Mensah, P. J. Houghton, R. A. Dickson, T. C. Fleischer, M. Heinrich and P. Bremner, "In-vitro Evaluation of Effects of Two Ghanaian Plants Relevant to Wound Healing", Phytother Res., 20, 941-944 (2006).

5- G. Y. Sy, R. B. Nongonierma, P. W. Ngewou, D. E. Mengata, A. M. Dieye, A. Cisse and B. Faye, "Healing Activity of Methanolic Extract of the Barks of Spathodea campanulata Beauv (Bignoniaceae) in Rat Experimental Burn Model", Dakar Med., 50, 77-81 (2005).

6- R. Scogin, "Anthocyanins of the Bignoniaceae," Biochem. Sys. Ecol., 8, 273-276 (1980).

7- S. Ngouela, E. Tsamo and B. L. Sondengam, "Extractives from Bignoniaceae: Constituents of the Stem Bark of Spathodea campanulata", Planta Med., 54, 476 (1988).

8- S. Ngouela, B. Nyasse, E. Tsamo, B. L. Sondengam and J. D. Connolly,"Sapthodic 
Acid: A Triterpene Acid from The Stem Bark of Spathodea campanulata," Phytochemistry, 29, 3959-3961 (1990).

9- S. Ngouela, E. Tsamo, B. L. Sondengam and J. D. Connolly, "Spathodol, a New Polyhydroxysterol from the Leaves of Spathodea campanulata", J. Nat. Prod., 54, 873-876 (1991).

10- S. Saxena, N. Pant, D. C. Jain and R. S. Bhakuni, "Antimalarial Agents from Plant Sources", Current Science, 85, 1314-1329 (2003).

11- E. J. T. Mbosso, S. Ngouela, J. C. A. Nguedia, V. Penlap, M. Rohmer and E. Tsamo, "Spathoside, a Cerebroside and Other Antibacterial Constituents of the Stem Bark of Spathodea campanulata", Nat. Prod. Res., 22, 296-304 (2008).

12- N. M. Nazif, "Phytochemical and Antioxidant activity of Spathodea campanulata P. Beauvois. Growing in Egypt", Natural Product Sciences, 13, 1116 (2007).

13- R. Gormann, M. Kaloga and H. Kolodziej, "Novel Flavonoids from Leaf Extracts of Markhamia acuminata and Spathodea campanulata", Planta Med., 72,35 (2006).

14- A. A. El-Hela, "Phenolics from Spathodea campanulata P. Beauvais Leaves", Az. J. Pharm. Sci., 27, 152-161 (2001).

15- S. S. Subramanian, S. Nagarajan and N. Sulochana, "Flavonoids of Eight Bignoniaceous Plants", Phytochemistry, 11, 1499 (1972).

16- S. S. Subramanian, N. Sulochana and S. Nagarajan, "Caffeic Acid from the Leaves of Spathodea campanulata", Current Science, 42, 403 (1973).

17- A. A. El-Hela, "A New Iridoid Glucoside from Spathodea campanulata P. Beauvais Leaves", Az. J. Pharm. Sci., 27, 115-119 (2001).

18- G. L. von Poser, J. Schripsema, A. T. Henriques and S. R. Jensen, "The Distribution of Iridoids in Bignoniaceae," Biochem. Sys. Ecol., 28, 351-366 (2000).

19- Y. G. Gouda, "Iridoids from Spathodea campanulata P. Beauvais Leaves", Natural Product Communications, 4, 753-756 (2009).

20- J. R. Trigo and W. F. Dos Santos, "Insect Mortality in Spathodea campanulata P. Beauvois Bignoniaceae Flowers", Revista
Brasileira de Biologia, 60, 537-538 (2000).

21- G. Niyonzima, G. Laekeman, M. Witrrouw, B. Van Poel, L. Pieter, D. Paper, G. De dercq, G. Franz and A. Vlietinck, "Hypoglycemic, Anticomplement and Anti-HIV Activities of Spathodea campanulata Stem Bark", Phytomedicine, 6, 45-49 (1999).

22- J. M. Makinde, O. O. Amusan and E. K. Adesogan, "The Antimalarial Activity of Spathodea campanulata Stem Bark Extract on Plasmodium berghei berghei in Mice", Planta Med., 54, 122-125 (1988).

23- O. O. G. Amusan, J. D. Msonthi and L. P. Makhubu, "Molluscicidal activity of Spathodea campanulata, Andrachne ovalis, Phytolacca dodecandra and Hypoxis rooperi", Fitoterapia, 66, 113116 (1995).

24- O. O. G. Amusan, E. K. Adesogan and J. M. Makinde, "Antimalarial Active Principles of Spathodea campanulata Stem Bark", Phytother Res., 10, 692-693 (1996).

25- P. J. Houghton, P. J. Hylands, A. Y. Mensah, A. Hensel and A. M. Deters, "Invitro Tests and Ethnopharmacological Investigations: wound Healing as an Example", J. Ethnopharmacol., 100, 100107 (2005).

26- R. Dhanabalan, A. Doss, S. Balachandar, E. Kezia, M. Jagadeeswari and H. Karthik, "In-vitro Phytochemical Screening and Antibacterial Activity of Organic Leaf Extracts of Spathodea campanulata P. Beauv Against Hospital Isolated Bacterial Strains", Ethnobotanical Leaflets, 12, 1022-1028 (2008).

27- K. Ofori-Kwakye, A. A. Kwapong and F. Adu, "Antimicrobial Activity of Extracts and Topical Products of the Stem Bark of Spathodea campanulata for Wound Healing", Afr. J. Trad. CAM., 6, 168-174 (2009).

28- E. E. Ilodigwe and P.A. Akah, "Spathodea campanulata: An Experimental Evaluation of The Analgesic and Antiinflammatory Properties of a Traditional Remedy", Asian Journal of Medical Sciences, 1, 35-38 (2009).

29- T. Kaneko, K. Ohtani, R. Kasai, K. Yamasaki and N. M. Duc, "n-alkyl 
Glycosides and p-hydroxybenzoyloxy Glucose from Fruits of Crescentia cujete", Phytochemistry, 47, 259-263, (1998).

30- K. Machida, M. Ando, Y. Yaoita, R. Kakuda and M. Kikuchi, "Phenolic Compounds of the Leaves of Catalpa ovata G. Don", Natural Medicines, 55, 6467 (2001).

31- Z. Jiang, Y. Hirose, H. Iwata, S. Sakamoto, T. Tanaka and I. Kouno, "Caffeoyl, Coumaroyl, Galloyl and Hexahydroxydiphenoyl Glucoses from Balanophora japonica", Chem. Pharm. Bull., 49, 887-892 (2001).

32- P. K. Agrawal, "Carbon-13 NMR of Flavonoids", Elsevier Science Publishing Company Inc., New York (1989).

33- J. B. Harborne and T. J. Mabry, "The Flavonoids: Advance in Research", Chapman and Hall Ltd. (1982).

34- T. J. Mabry, K. R. Markham and M. B. Thomas, "The Systematic Identification of Flavonoids". Springer-Verlag, New York, Heidelberg, Berlin (1970).
35- Z. He, S. Ueda, M. Akaji, T. Fujita, K. Inoue and C. Yang, "Monoterpenoid and Phenylethanoid Glycosides from Ligustrum pedunculare", Phytochemistry, 36, 709-716, (1994).

36- L. Fakras, B. Vermes, M. Nogradi and A. Kalman, "The Final Structure of Robinin and Biorobin and their Total Synthesis", ibid., 15, 215-218 (1976).

37- S. Gafner, J. L. Wolfender, M. Nianga and K. Hostettmann, "Phenylpropanoid Glycosides from Newbouldia laevis Roots", ibid., 44, 687-690 (1997).

38- H. Nishimura, H. Sasaki, T. Morota, M. Chin and H. Mitsuhashi, "Six Glycosides from Rehmannia glutinosa var. purpurea", ibid., 29, 3303-3306, (1990).

39- H. Sasaki, H. Nishimura, M. Chin and H. Mitsuhashi, "Hydroxycinnamic Acid Esters of Phenethylalcohol Glycosides from Rehmannia glutinosa var. purpurea", ibid., 28, 875-879 (1989). 